\title{
K. Kuperan
}

Nik Mustapha

Raja Abdullah

Department of Natural Resource Economics

Faculty of Economics and Management

Universiti Putra Malaysia

43400 UPM Serdang

Selangor, Malaysia

\section{Robert S. Pomeroy}

E. Genio

A. Salamanca

ICLARM

MC. P.O. Box 2631

Makati, Metro Manila 0718 Philippines

Fax: 6328163183

Email: R.POMEROY@CGNET.COM

Stream: Fisheries

\section{MEASURING TRANSACTION COSTS OF FISHERIES CO-MANAGEMENT}

The authors are grateful for financial support from ICLARM and UPM

for this research under the International Collaborative Project on

Fisheries Co-management funded by DANIDA.

\begin{abstract}
Fisheries co-management as an alternative to centralised command and control fisheries management is often suggested as a solution to the problems of fisheries resource use conflicts and overexploitation. Various researchers have talked of the importance of studying the role of transaction costs between different intitutional arrangements for managing fisheries resources. There have howerver been no attempts to verify empirically by measuring the transactions costs involved in fisheries management This paper provides some measurements of the transaction costs under a fisheries co-management system. The transaction costs can be categorised into three major cost items. These are (1) information costs, (2) collective fisheries decision-making costs, and (3) collective operational costs. The transaction costs of fisheries co-management in San Salvador Island, Philippines is presented. The method of collecting information about transactions cost of fisheries co-mangement had not be attempted anywhere before. Information on the cost of a wide range of transaction costs variables were collected. The costs are used to assess the relative importance of the various transactions costs in a co-managed and a
\end{abstract}


centrally managed system. The difference in the transaction costs between a centraly manged and a co-managed system is used as a basis for public policy decisions on the choice of alternative institutional arrangemens for managing a fishery.

Keywords Transaction Costs, Fisheries Co-management, Institutions, Information Costs, Collective Fisheries Decision-Making Costs, Collective Operational Costs.

\section{Introduction}

One of the purported advantages of co-management compared to centralized management is that it will reduce transaction costs - the cost of gaining information about the resource and what users are doing with it, reaching agreements and coordinating with others in the group with respect to use of the resource, and enforcing agreements that have been reached. Hanna (1995) points out that a centralized approach is often associated with low program design costs but high implementation, monitoring and enforcement costs as the management regime may have little legitimacy with user groups. A co-management approach, on the other hand, is associated with high program design costs as effective participation is time-consuming and therefore costly. However, co-management is likely to lead to lower implementation, monitoring and enforcement costs as legitimacy of the regime is greater.

The objective of this paper is to provide some measurements of the transaction costs in a co-managed fisheries. A comparison of the transaction costs with a centralised system of fisheries management is made and some implications for public policy on the choice of centrally versus co-managed systems are discussed.

In section two of the paper a brief definition of co-management and transaction costs are presented. The third section of the paper provides information on fisheries co-management experience in San Salvador Island, Philippines. This is followed by a discussion of the measurement of the transaction costs and the data collection methods used. The results are then presented and the policy implications of the results form the final part of the paper.

\section{Fisheries Co-Management}

Fisheries co-management is defined as the sharing of responsibility and authority between the government and the community of local fishers to manage a fishery (Pomeroy and Williams 1994; Sen and Nielsen 1996). Co-management covers various partnership arrangements and degrees of power-sharing and integration of local and centralized management systems. There is a hierarchy of co-management arrangements from those in which the fishers are merely consulted by the government before regulations are introduced, to those in which fishers design, implement and enforce laws and regulations with advice and assistance from the government (Figure 1). The amount of responsibility and authority that the state and various local levels have will differ and depend upon country-specific and site-specific conditions, and is 
ultimately a political decision.

The delegation of significant responsibility and authority to manage the fisheries may be one of the most difficult tasks in establishing co-management systems. While governments may be willing to call for more user participation, they must also establish commensurate rights and authorities and devolve some of their own powers. Government resource managers are often reluctant to share their authority or parts of it. Many managers fear a loss of political power or infringement on their professional and scientific turf. Fishers will need to take some of the responsibility of convincing managers of their ability to undertake local-level resource

management. In all cases of co-management, the ultimate authority is held by the government.

\section{Transaction Costs in Fisheries Co-Management}

Transaction costs economics was first discussed in the economic literature by Ronald Coase (1937) in his seminal paper "The Nature of the Firm". Coase proposed that the decision whether to have a transaction within a firm or in the market place will be determined by transaction costs (Coase, 1937). He suggested that the form of control (the firm or the market) chosen would tend to be the one with the lowest transaction costs. This early analysis eventually spawned a great deal of theoretical work known as transaction cost economics. This theory suggests, if given a choice, individuals will choose the set of institutions, contracts or transactions that will minimize the (transaction) costs of doing business. Coase went on to say that a contract that offers the lowest transaction costs will tend to be used the most to govern a set of actions. However, as Libecap (1991) points out, having lower transaction cost is a necessary rather than a sufficient condition for adoption. It is therefore appropriate to examine transaction costs when evaluating the potential of new institutions as alternatives to existing institutions. A number of useful definitions of transaction costs are available in the literature such as Williamson (1973, 1975, 1981), Randall (1972), Dahlman (1979), North (1990), Davis (1986), Barzel (1989) and Cheung (1969).

When multiple individuals are involved in environments where complex activities must be co-ordinated across space and over time, they may attempt to reduce the substantial uncertainties they face through various forms of implicit or explicit agreements. These contracts involve costly activities expended in the processes of achieving agreements before and continuing to co-ordinate activities after an initial agreement is reached in an uncertain environment. Williamson (1985) identifies the costs associated with contracting activities as ex ante and ex post transaction costs. Using the generic of the Williamson's transaction cost economics, the transaction cost in fisheries co-management can therefore be broadly categorized into three major cost items: (1) information costs; (2) collective fisheries decision-making costs; and (3) collective operational costs. The first two categories are ex ante transaction cost while the latter is defined as the ex post transaction cost. This breakdown is largely based on anecdotal information and the schematic flow diagram of the transaction costs in fisheries co-management is shown in figure 2. The transaction costs arise from the problems of information, co-ordination and control that stem primarily from the fact that fisheries resource management decisions involve multiple 
actors with different interest in long term, interdependent and uncertain processes. A detailed discussion on these three costs items can be found in Nik Mustapha et al (1998).

The key factor that differentiates centralised management from co-management is the level of user participation in the design and implementation of the management activities namely, resource assessment, determining management objectives, selecting management measures, allocating the resource among users, allocation of the resource over time, and enforcing regulations. The extent to which the state allows for user participation for each of the management activities determines the spectrum of different co-management arrangements possible between the state and the users. The expected level of transaction costs involved for each of the different management activities under a pure centralised management system compared with a co-management system with a high level of user participation is shown in Table 1

\section{Overview of the Fisheries Co-Management Experience of San Salvador}

San Salvador, an island barangay (village) of Masinloc municipality in the province of Zambales, is located on the western coast of Luzon in the Philippines. It does not have a well-defined tradition of fisheries management of its own, having been inhabited largely by farmers who came from the mainland of Zambales Province (Christie, White, and Buhat 1993). Consequently, a strong indigenous tradition of fish stock management is virtually non-existent.

Before World War II, fishers recalled that San Salvador was marked by abundant marine resources, use of non-destructive fishing methods, and a relatively homogeneous population. Consequently, there was no need for property rights and rules to govern fishing activities. Competition for resource use was not a problem, given the rich fishing grounds, a small population, and non-integration of the village economy into export markets. Thus, access to the fishery was unrestricted.

During World World II (early 1940s), Japanese troops occupied the island of San Salvador and sometimes used explosives to catch fish, marking the early beginnings of blast fishing in the area. After World War II and until the 1960s, most village fishers continued to use non-destructive, traditional fishing methods such as hook and line, improvised speargun, and gill nets. Also used was kunay, a beach seine with a long scareline of coconut fronds for herding fish from the reef flat into a fine mesh net $(5-\mathrm{cm}$ net). Women often gleaned in shallow reefs. Local fisheries in the 1960s easily met the subsistence needs of the village residents. Farming provided additional livelihood for the island's residents.

The1970s ushered in an influx of Visayan migrants who were searching for better fishing grounds and decided to settle in San Salvador, particularly in Cabangun (now Purok Maligaya) where they purchased a piece of land. Relatives soon joined the initial batch of Visayan migrants. The decade, moreover, saw a pronounced shift to non-traditional and destructive fishing operations such as blast fishing, aquarium fish collection using sodium cyanide, and spear fishing with air compressors, which 
eventually devastated San Salvador's fishing grounds. The increased deployment of fine mesh nets aggravated the indiscriminate harvest of large and small fish alike. The 1970s also marked the integration of San Salvador into an export-oriented market for aquarium fish via middlemen who visited the village. The Visayan migrants, in particular, were catching aquarium fish for a growing market in the United States and Europe. Historically, aquarium fish gatherers used sodium cyanide, which damages the reef.

The lack of knowledge of marine ecosystems and the long-term effects of destructive fishing methods could have led to irreversible damage were it not for the timely intervention of external catalysts. In March 1987, Patrick Christie arrived in San Salvador as a Peace Corps volunteer working with the Bureau of Fisheries and Aquatic Resources (BFAR). For about a year, he was instrumental in assessing the needs of San Salvador, the level of environmental awareness of village residents, and existing reef conditions. He initiated dialogues with village officials, the municipal mayor, non-government organizations, and the Bureau of Fisheries and Aquatic Resources under the Department of Agriculture (DA). In the process, he drummed up support for rehabilitating the fishery resources of San Salvador. Thus, the concept of a marine sanctuary emerged in 1988.

A project proposal on the Marine Conservation Project for San Salvador (MCPSS), prepared by Patrick Christie, was approved and funded by the Netherlands Embassy and the Jaime V. Ongpin Foundation from 1989 to 1991 for US\$17,000. Additional financial support beyond the two-year period came from the World Wildlife Fund Debt-for-Nature Swap program until 1993. The Haribon Foundation, as the implementing non-government organization (NGO), provided personnel and logistical support to the project. Haribon was one of the first Philippine environment groups to recognize the role of the community in managing and sustaining resource management projects. The MCPSS may be regarded as a milestone, being the first marine sanctuary established in Luzon (a major geographical region in the northern part of the Philippines).

The subsequent passage of Municipal Ordinance No. 30, series of 1989, by the Municipal Government of Masinloc lent legitimacy to the effort to protect and rehabilitate San Salvador's remaining resources as well as apprehend violators. It also provided an opportunity for the municipal government and the village of San Salvador to cooperate in fisheries management.

From 1989 to 1993, the Haribon Foundation, Municipal Government of Masinloc, and the San Salvador community jointly implemented the MCPSS. In 1993, the Haribon Foundation turned over the project to the people's organization (PO) it helped establish, known as the Samahang Pangkaunlaran ng San Salvador (SPSS), in an emotional ceremony that ended four years of community organizing work.

The municipal mayor of Masinloc adopted the project and has since become an active partner of the SPSS and the village government, reaping public recognition afterwards as a result of his active involvement in the management of the marine 
sanctuary of San Salvador. Despite the phase-out of the Haribon Foundation in 1993, project initiatives were sustained by the village and the municipal government, demonstrating that they could share responsibility for fisheries management. The MCPSS, which adopted a community-based approach to resource management, was a vital springboard for making co-management prosper in San Salvador.

\section{Data Collection and Sampling}

The data collection method has several steps and processes aimed at collecting cost and time-spent information in running the marine conservation project in San Salvador from its inception in the late 80's to the present. Time horizon for the marine conservation project in San Salvador was divided into 3 stages. Stage I, is defined to be inception stage wherein people in San Salvador started conceptualising and implementing the first phase of the marine conservation project (Year 1988-1989). Stage II, is defined to be the stage wherein the local island organisation (LTK/SPSS) in partnership with Haribon Foundation went ahead on the full implementation of the project (Year 1990-1993). Stage III, is the stage wherein management of the sanctuary has been completely turned over by the Haribon Foundation to the SPSS to be run autonomously by the local people's organisation (1994-Present).

Steps in collecting relevant time and monetary expenditure cost for all stages include: (1) a full scale survey on 62 respondent's (31 member, 31 non-member) participation on the marine conservation project for stage III; (2) a key-informant interview on core members participation in terms of the time, effort and cost of setting-up the project for stage I and II; (3) a literature and key-informant data gathering on government's participation on the marine conservation project in San Salvador and other related projects in other areas.

The full scale survey of the 62 respondents for stage III entailed the hiring of 8 manila based Haribon volunteers to assist in administration of the survey questionnaires to the prospective respondents. To provide the volunteers with a firm understanding of the objectives of the study, survey instruments, the training of field enumerators preceded the actual survey of fishing households. During the actual survey, daily meetings with the enumerators took place at the end of the day primarily to review the survey results.

The sample of respondents for the survey was drawn from an updated list of barangay households whose primary occupation is fishing. The sample respondents from the list was then categorised as members and non-members of the SPSS (Samahang Pangkaunlaran ng San Salvador), a local livelihood association in the island running and taking care of the marine sanctuary project. The survey team gathered information on respondent's participation and contribution to the marine conservation project in terms of time, effort and money spent in trying to make the project work.

The sample size of 62 was based on power analysis described by Cohen (1988), and included two sample groups of 31 each: members of the fishers' 
association and non-members. Power analysis concerns the probability of detecting a statistically significant relationship in a sample when in fact there is a notable difference in the population. Any given sample may fail to result in a statistically significant finding, even when there is a significant difference in the population. Therefore, to increase the probability that the research design can find a statistically significant difference, if one exists, the concept of "power" is used to determine sample size.

Prior to conducting the power analysis, the following assumptions were made: 1) the alpha is set at 0.05, two-tail and 2) the sample size for each group equals 31 . With the sample size of 31 in each of two groups, the power of the statistical design -or probability that any given sample would have statistically significant differences -would be greater than 0.93 using a two-tailed test. Applying a one-tailed statistical test increases the power to greater than 0.97 . Table 2 illustrates the power associated with group samples ranging from 9 to 25 in each group, using both one- and two-tailed tests.

Table 2. Power analysis for different sample sizes

\begin{tabular}{lrr}
\hline Group size & Two-Tail & One-Tail \\
\hline 25 & .93 & .97 \\
23 & .91 & .95 \\
21 & .88 & .94 \\
19 & .85 & .92 \\
17 & .80 & .89 \\
15 & .75 & .85 \\
13 & .68 & .80 \\
11 & .60 & .73 \\
9 & .51 & .65 \\
\hline
\end{tabular}

A key informant interview on some of the original proponents (core members) of the sanctuary was also done in order to account for time and money spent by this people in setting up the project. Core members were asked to recall and estimate the time and money they put-up in the project's stage I and II phase of development. This development phase include activities such as information and educational campaigns, establishment of supplemental livelihood projects, construction of guard houses and the establishment of beach patrols to help maintain the sanctuary. Old project files detailing the costs and the extent of participation of private organisations such as the Jaime V. Ongpin Foundation and Haribon Foundation was also used to keep track of all monetary inputs to the project.

Literature and key-informant information was again used to assess and estimate the cost of a centralised management system under the supervision and control of government line agencies such as the Coastal Environmental Project of the Department of Environment and Natural Resources (CEP-DENR), Bureau of Fisheries and Aquatic Resources (BFAR), Philippines National Police (PNP) and the Philippine Coast Guard in the Masinloc bay area from 1988-1996.

Cost estimates from government financed management system would then be compared vis-à-vis the site managed under a co-management system in terms of cost, 
efficiency and overall effectivity in preventing resource degradation.

\section{Results}

The results obtained for the San Salvador area for the period 1988-1996 as shown in Table 3 indicate that the difference in the total costs of fisheries management between centalised governemnt management and co-management is not that significant. However there is significant difference in the costs at the different stages of management. In stages one and two, which are the stages of initiating a new management regime and community education, the costs are higher for the comanagement approach compared to the centralised government approach The costs are however lower in the third stage for a co-managed approach when monitoring and enforcement and conflict resolution become important (see figure 4). These findings appear to be consistent with Hanna's (1995) view that the downstream or implementation costs are likely to be lower for a co-managed approach. This is because the cost of monitoring and enforcement are likely to be lower as community members are more likely to comply with rules and regulations developed by the community as a whole as oposed to regulations imposed by an external regulatory authority. This is important from a policy perspective as the the implementation costs are the costs encounted on a perpetual basis as the maangement intitutions are implemented. This could result in a overall lower cost of managing the fisheries resources for the society.

Table 3 Costs of Fisheries Management

\section{Costs of Alternative Institutional Arrangements for Fisheries Management in} San Salvador

\begin{tabular}{|l|l|l|l|l|}
\hline $\begin{array}{l}\text { Government } \\
\text { Management }\end{array}$ & $\begin{array}{l}\text { Total } \\
(1988-1996\end{array}$ & $\begin{array}{l}\text { Stage 1 } \\
(89-90)\end{array}$ & $\begin{array}{l}\text { Stage 2 } \\
(91-92)\end{array}$ & $\begin{array}{l}\text { Stage 3 } \\
(93-96)\end{array}$ \\
\hline $\begin{array}{l}\text { National } \\
\text { Government }\end{array}$ & $\mathbf{3 , 3 5 1 , 3 3 0}$ & $\mathbf{4 3 8 , 5 7 5}$ & $\mathbf{4 5 0 , 9 0 2}$ & $\mathbf{2 , 4 6 1 , 8 5 3}$ \\
\hline $\begin{array}{l}\text { Local } \\
\text { Government }\end{array}$ & $\mathbf{3 9 3 , 9 5 4}$ & $\mathbf{8 , 3 2 0}$ & $\mathbf{1 6 , 6 4 0}$ & $\mathbf{3 6 8 , 9 9 4}$ \\
\hline Total & $\mathbf{3 , 7 4 5 , 2 8 4}$ & $\mathbf{4 4 6 , 8 9 5}$ & $\mathbf{4 6 7 , 5 4 2}$ & $\mathbf{2 , 8 3 0 , 8 4 7}$ \\
\hline $\begin{array}{l}\text { Co- } \\
\text { management }\end{array}$ & $\mathbf{1 , 4 3 0 , 5 2 2}$ & $\mathbf{7 3 7 , 2 7 2}$ & $\mathbf{5 7 3 , 2 5 0}$ & $\mathbf{1 2 0 , 0 0 0}$ \\
\hline $\begin{array}{l}\text { Direct cash } \\
\text { infusion }\end{array}$ & $\mathbf{2 , 4 3 0 , 0 0 0}$ & $\mathbf{8 1 0 , 0 0 0}$ & $\mathbf{5 4 0 , 0 0 0}$ & $\mathbf{1 , 0 8 0 , 0 0 0}$ \\
\hline $\begin{array}{l}\text { Counterpart } \\
\text { labour }\end{array}$ & $\mathbf{3 , 8 6 0 , 5 2 2}$ & $\mathbf{1 , 5 4 7 , 2 7 2}$ & $\mathbf{1 , 1 1 3 , 2 5 0}$ & $\mathbf{1 , 2 0 0 , 0 0 0}$ \\
\hline Total & & & & \\
\hline
\end{tabular}


Table 4 gives a break down of the time spent on the various activities in a comanagement system. It is clear that monitoring takes up the bulk of the time as it is a continuous day to day activity and is a crucial activity for the maintainance of the institution. The fact that monitoring takes up more than half of the total time of the fishers involved in the co-management project indicates the importance of this activity and also helps to explain the lower costs for co-mangement in stage 2 and 3 as discussed above. If the rules are well received by the members as in the case of comanagement the resources spend on monitoring could be lower thus explaining the lower costs for co-mangement in stage 3 of the project compared to government management. When seen in monetary terms again the monitoring activity emerges as the activity accounting for more than fifty percent of the total costs of all the activities involved in co-management.

\section{Policy Implications}

The general theoretical arguments that transactions cost may be lower under a comanaged system appears to have some support from the data used in this study. Although direct comparisions between a co-managed and centrally managed systems are difficult to make as clear cut examples of that nature are hard to come by in the real world, in this study a small Island in the Philippines that has experimented with the idea of co-management provides an opportunity for such comparisons. There are serious problems with comparisons of this nature as both the co-managed arrangement and the centralised government based managed are present at the same time. But results from this study indicate that since monitoring costs are the major transaction costs and it is undertaken by the commnity there is opportunity for these costs to decline over time as the community acceptance of the rules and regulations for managing the common property as have greater moral obligation to obey those rules and regulations. As shown in figure 4 the costs of managing the common property is lower in the later years(e.g. from the fifth year onwards) under a co-manged regime than under a purely government management regime. 


\section{References}

Barzel, Yoram. 1989. The Economic Analysis of Property Rights. New York: Cambridge University Press.

Baland, J.M. and J.P. Platteau. 1996. Halting Degradation of Natural Resources - Is There a Role for Rural Communities. Oxford: FAO/Clarendon Press.

Berkes, F. 1994. Co-Management: Bridging the Two Solitudes. North. Perspect., 22(2-3): $18-20$.

Berkes, F. 1992. "Success and Failure in Marine Coastal Fisheries of Turkey. In D.W. Bromley, David Feeny, Margaret McKean (eds.). Making the Commons Work: Theory, Practice, and Policy, San Francisco: Institute for Contemporary Studies.

Bromley, D.W. 1991. Environment and Economy: Property Rights and Public Policy Cambridge, MA: Blackwell.

Bromley, D.W. 1992. The Commons, Property and Common Property Regimes. In D.W. Bromley et.al. (eds.) Making the Commons Work: Theory, Practice and Policy, San Francisco : Institute for Contemporary Studies.

Carlos, M.B. and R.S. Pomeroy. 1996. A Review and Evaluation of Community Based Coastal Resource Management Programs and Projects in the Philippines, 1984-1994. Research Report No. 6. Fisheries Co-management project, ICLARM, Manila, Philippines.

Cheung, Steven N.S. 1969. Transaction Costs, Risk Aversion, and the Choice of Contractual Arrangements. Journal of Law and Economics, 12(1): 23-42.

Coase, R. 1937. The Nature of the Firm. Economica, 4: 386-405.

Dahlman, Carl J. 1979. The Problem of Externality. Journal of Law and Economics, 22: 141-162.

Davis, Lance E. 1986. Comment. In Stanley L. Engerman and R.E. Gullman (eds.), Long-Term Factors in Economic Growth. Chicago, University of Chicago Press: 149-159.

Demsetz, Harold. 1964. The Exchange and Enforcement of Property Rights. Journal of Law and Economics, 7: 11-26.

Review, 57: 347-359. 1967. Towards a Theory of Property Rights. American Economic

Dubbink, W. and M. Van Vliet 1996. Market Regulation Versus Co-Management? Two Perspectives on Regulating Fisheries Compared. Marine Policy 20(6): 499-516. 
Feeny, D. 1995. Optimality, Sub-Optimality, Nirvana, and Transaction Cost: Foraging on the Commons. Presidential Address at the Fifth Meeting of the International Association for the Study of Common Property, Bodo, Norway, May 25.

Feeny, D., F. Berkes, B.J. Mc Cay and J.M. Acheson. 1990. The Tragedy of the Commons: Twenty-two Years Later. Human Ecology. 18:1-19.

Gibbs, C.J.N. and D.W. Bromley. 1989. Institutional Arrangements for Management of Rural Resources: Common Property Regimes. In F. Berkes (ed.) Common Property Resources. London: Belhaven Press.

Griffin, Ronald C. 1991. The Welfare Analytics of Transaction Costs, Externalities and Institutional Choice. American Journal of Agricultural Economics, 73(3): 601-614.

Hanna, S. 1995. Efficiencies of User Participation in Natural Resource Management. In Hanna, S. and M. Munasinghe (eds.) Property Rights and the Environment - Social and Ecological Issues. Biejer International Institute of Ecological Economics and The World Bank. Washington, D.C.

Hanna, S., C. Folke and K.G. Maler (eds) 1996. Rights to Nature, Washington, DC: Beijer International Institute of Ecological Economics, Stockholm and Island Press.

Jentoft, S. 1989. Fisheries Co-management. Marine Policy 13: 137-154.

Jentoft, S. and B. McCay 1995. User Participation Fisheries Management: Lessons Drawn From International Experience. Marine Policy. 19(3): 227-246.

K. Kuperan. Status of the Fisheries Sector in Malaysia, Illegal Fishing and the Economics of Enforcement. Paper Presented at a Conference on the Contribution of the Marine Sector to the National Economy, Organized by the Malaysian Institute of Maritime Affairs, Kuala Lumpur, 30 November 1994, 25p.

Libecap, Gary. 1991. Contracting for Property Rights, Cambridge: Cambridge University Press.

McCay, B.J. 1993. Management Regimes Beijer Discussion Paper Series No. 38. Beijer International Institute of Ecological Economics, Stockholm, Sweden.

McCay, B.J. and J.M. Acheson (eds) 1987. The Question of the Commons: The Culture and Ecology of Communal Resources. Tucson: University of Arizona Press.

McCay, B.J. 1995. Commons and Private Concerns. Advances in Human Ecology. 4: 89116.

McCay, B.J. and S. Jentoft 1996. From the Bottom Up: Participatory Issues in Fisheries Management. Society and Natural Resource 9: 237-250. 
North, Douglas C. 1990. Institutions, Institutional Change and Economic Performance. Cambridge: Cambridge University Press.

Ostrom, E. 1990. Governing the Commons, the Evolution of Institutions for Collective Action. Cambridge: Cambridge University Press.

Ostrom, E. 1992. Crafting Institutions for Self Governing Irrigation Systems, San Francisco: Institute of Contemporary Studies Press.

Pinkerton, Evelyn. 1989. Co-Operative Management of Local Fisheries - A New Direction for Improved Management and Community Development. Vancouver: University of British Columbia Press.

Pomeroy, Robert S. and M.J. Williams. 1994. Fisheries Co-Management and Small-Scale Fisheries: A Policy Brief. International Center for Living Aquatic Resources Management, Manila, 15p.

Randall, Alan. 1972. Market Solutions to Externality Problems: Theory and Practice. American Journal of Agricultural Economics, 54: 175-83.

Runge, C.F. 1992. Common Property and Collective Action in Economic Development. In D.W. Bromley et.al. (eds) Making the Commons Work: Theory, Practice and Policy. San Francisco: Institute of Contemporary Studies Press.

Sen, S. and J. Raakjaer Nielsen 1996. Fisheries Co-Management: A Comparative Analysis. Marine Policy. 20(5): 405-418.

Smith, A.H. and F. Berkes. 1993. Community-based Use of Mangrove Resources in St. Lucia. International Journal of Environmental Studies 43: 123-132.

White, A.T., L.Z. Hale, Y. Renard and L. Cortesi (eds) 1994. Collaborative and Community Based Management of Coral Reefs: Lessons from Experience. West Hartford, Conn: Kumarian Press.

Williamson, O.E. 1973. Market and Hierarchies: Some Elementary Considerations. American Economic Review, 63: 316-25.

Williamson, Oliver E. 1975. Markets and Hierarchies: Managerial Objectives in a Theory of the Firm. New York: Free Press.

Williamson, Oliver E. 1981. The Modern Corporation: Origins, Evolution, Attributes. Journal of Economic Literature, 19(4): 1537-1568.

Williamson, Oliver E. 1985. The Economic Institutions of Capitalism: Firms, Markets, Relational Contracting. New York: Macmillan. 
Table 1: Transaction Costs in Centralised and Co-managed Systems

\begin{tabular}{|l|l|l|}
\hline Resource Management Activities & Centralised Management & Co-Management \\
\hline $\begin{array}{l}\text { Information seeking } \\
\begin{array}{l}\text { Decision making and Setting } \\
\text { management objectives }\end{array}\end{array}$ & low & high \\
$\begin{array}{l}\text { Resource distribution among } \\
\text { users }\end{array}$ & high & high \\
$\begin{array}{l}\text { Resource distribution over time } \\
\text { Monitoring, enforcement and } \\
\text { compliance }\end{array}$ & high & low \\
$\begin{array}{l}\text { Resource maintenance } \\
\text { high }\end{array}$ & high & low \\
\hline
\end{tabular}




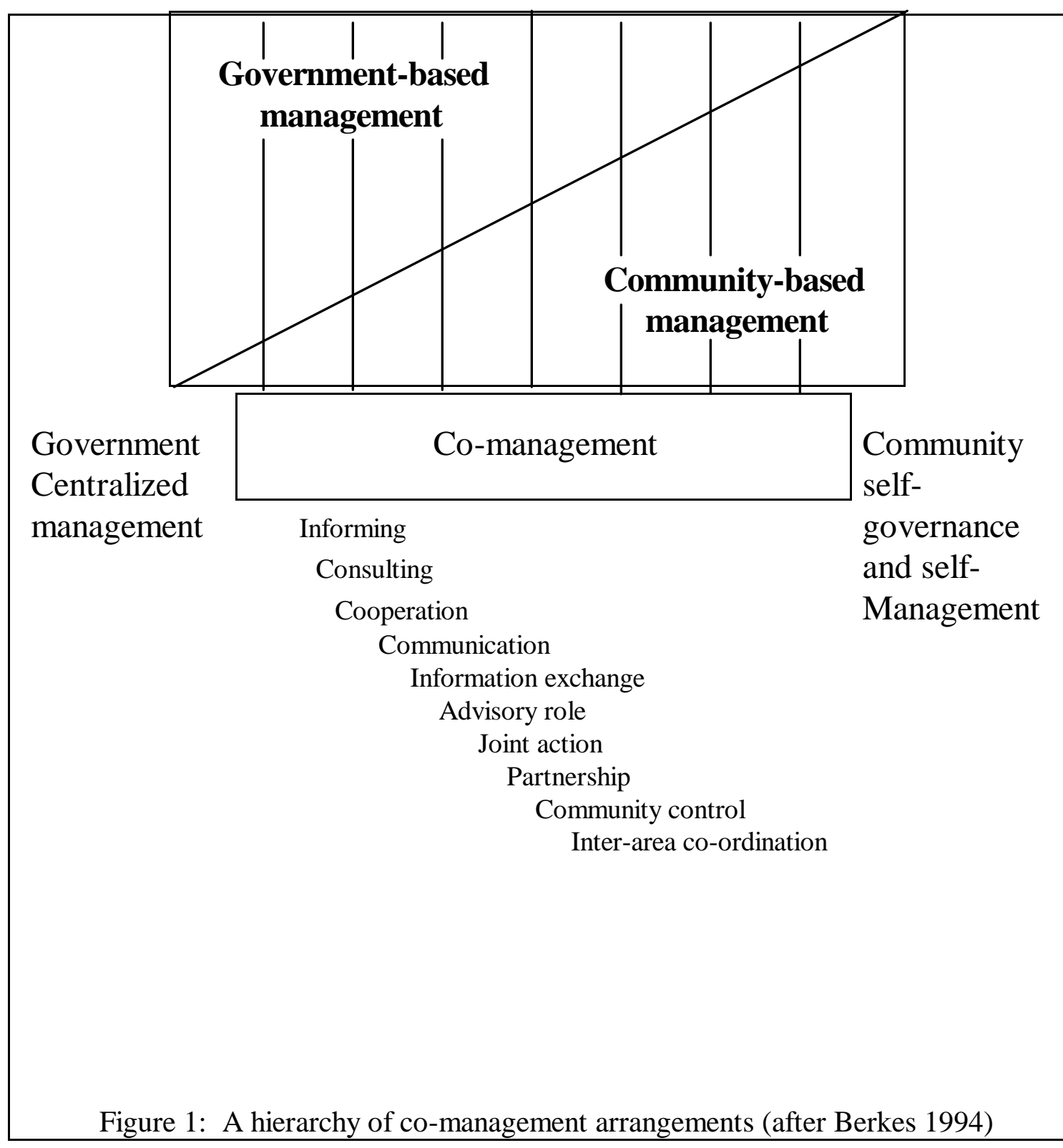




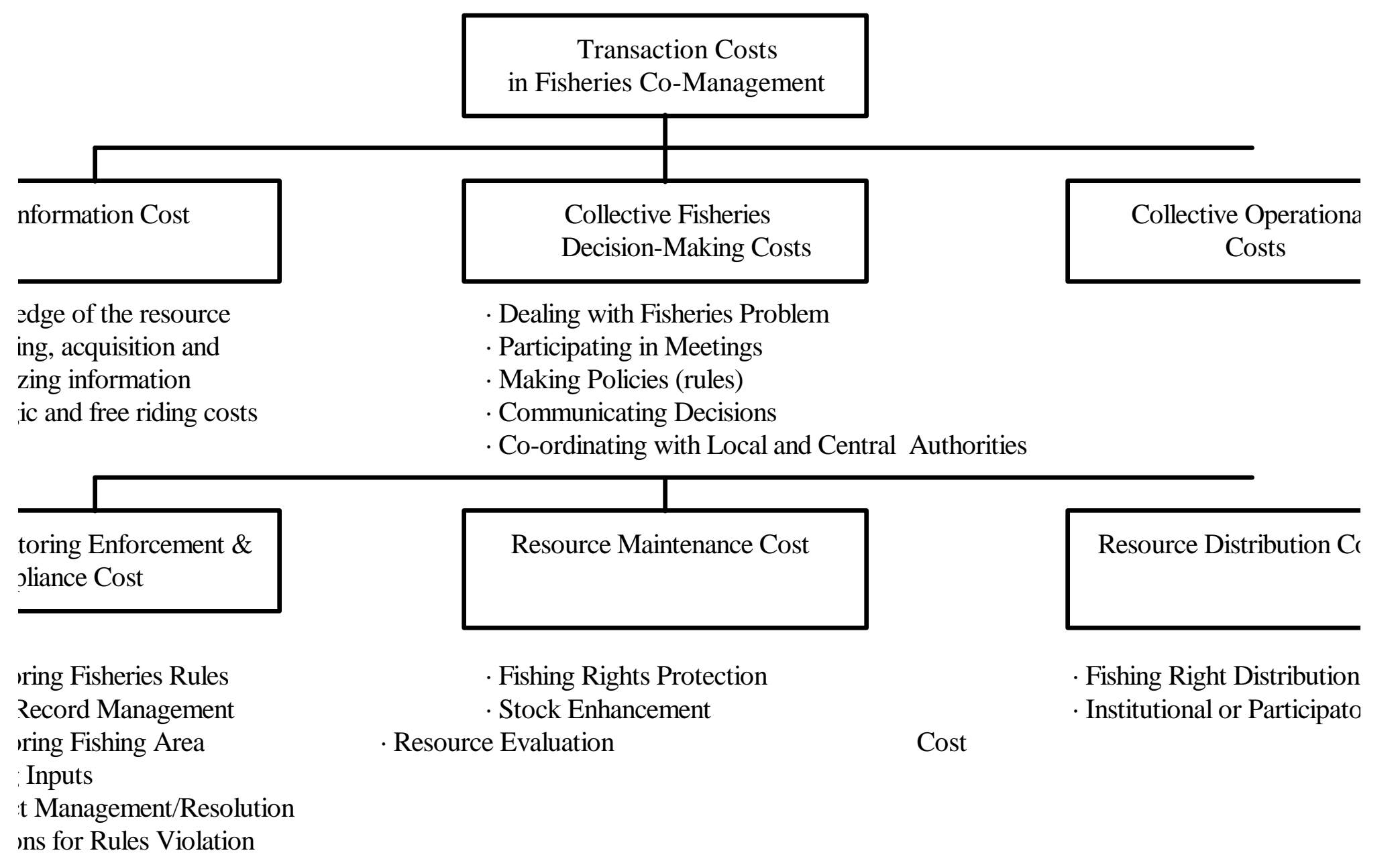

Figure 2: The Schematic Flow Diagram of the Transaction Costs in Fisheries Co Management 
Existing Management Regime Inadequate

Time

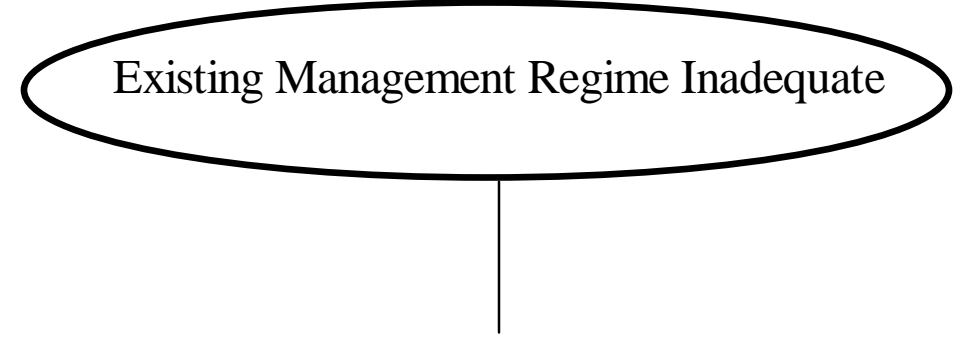

$0 \begin{aligned} & \text { Recognition of Need for New Management Regime } \\ & \text { Discussion/Meetings } \\ & \text { Information } \\ & \text { Organizing/Leadership } \\ & \text { Definition of Management Objectives and Strategies }\end{aligned}$

Development of Institutional Arrangements

Community Education

Adjustment of Institutional Arrangements

Stage 2

Monitoring and Enforcement

Maintaining Institutional Arrangements

Adjudicating Conflicts

Sanctioning Violators

Adjustments in Institutional Arrangements

Stage 3

$\mathbf{t}$

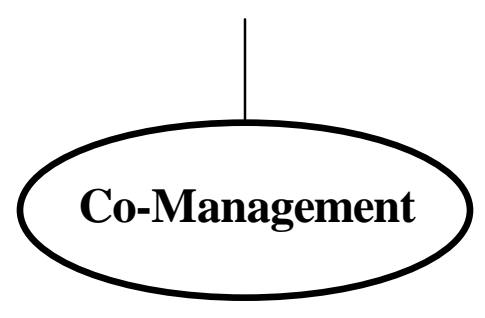

Figure 3: Process of Moving Towards Co-Management

Source: Modified from White et.al. (1994). 


\section{COST TABLE (Graph) EXPLANATIONS}

Co-Mgt Cost of protecting the marine resources of San Salvador island is comprised mostly of the following inputs (1) Monetary infusion (seed money) from NGOs, mainly JVOFI and Haribon Foundation to start-up the project; (2) Cash expenses borne by the residents of the island in participating in the project (mostly in the form of food, fuel and transportation cost estimated at P30,000 a year); and (3) Counterpart labor provided by the local resident needed to run the Marine Conservation Project. Cost data collected from San Salvador spans 9 years from the inception of the project and is divided into 3 distinct stages. Stage 1 is characterized as the inception stage of the project spanning 3 years (8890 ), it is during this time that the preliminary structures of community based resource management is being laid down and introduced to the stakeholders. Stage 2 (91-92) is the implementing stage wherein most of co-management and institutional structures of the project are in place and is smoothly being implemented both by the local people with the help of the NGOs. Stage 3 (93-96) is the turnover stage wherein operational control of the project was turned over to the local stakeholders.

Cost incurred for Stage 1 and 2 of the project is composed mostly of money spent by the NGOs for training, education, setting up of the of the co-mgt structures in the island; and opportunity cost of counterpart labor and incidental expenses of the local stakeholders of the project. Cost incurred for Stage 3 consists of mainly (opportunity cost) counterpart labor and incidental expenses after outside sources of funding have come to an end after the turnover.

Co-Mgt1 (see Cost table) shows the all the cost (monetary cost plus opportunity cost of counterpart labor) associated with the Co-management style of resource management, while Co-Mgt2 shows only the direct monetary cost associated with the project.

Government cost associated with managing the resources around San Salvador island is composed of the following: (1) enforcement cost by the Philippine Maritime Police and the local Coast Guard Unit; (2) expenditures by the Local Government Unit (LGU) on the Bantay Bagat Program (Guardians of the Sea Program), the Local Municipal Agricultural Office (MAO); and (3) National Government expenditures through the Department of Environment and Natural Resources' Coastal Environmental Program (DENR-CEP) and support to the local Municipal Agricultural Office (MAO) prior to the devolution of state functions in favor of the Local Government in 1992.

Govt 1 shows all the cost incurred by the government in managing the coastal resources in San Salvador from 1988-96. Govt2 shows all the cost incurred by the government with the exception of the DENR-CEP program which started only 1993 and whose future is variable and contingent upon the yearly budget appropriations from the Philippine Congress. 
COST OF ALTERNATIVE INSTITUTIONAL ARRANGEMENTS FOR FISHERIES MANAGEMENT IN SAN SALVADOR

Local Government and

Total (1988-1996) $\underline{\text { Stage 1(88-90) }}$

Stage 2 (91-92)

$\underline{\text { Stage } 3}$

National government

Expenditure

National Government
Local Government

TOTAL

Co-Management or Self-managed Expenditures

Direct Cash Infusion
Counterpart Labor

TOTAL
$3,351,330$

393,954

$3,745,284$

$1,430,522$

$2,430,000$

$3,860,522$
438,575

8,320

446,895

737,272

810,000

$1,547,272$
(93-96)

$\begin{array}{rr}450,902 & 2,461,853 \\ 16,640 & 368,994 \\ 467,542 & 2,830,847\end{array}$

573,250

120,000

$540,000 \quad 1,080,000$

$1,113,250 \quad 1,200,000$ 
Figure 4 : Costs of Alternative Fisheries Management Systems in San Salvador, Philippines

\section{Co-Mgt and Centralised Cost of Managing the Coastal Resources of San Salvador}

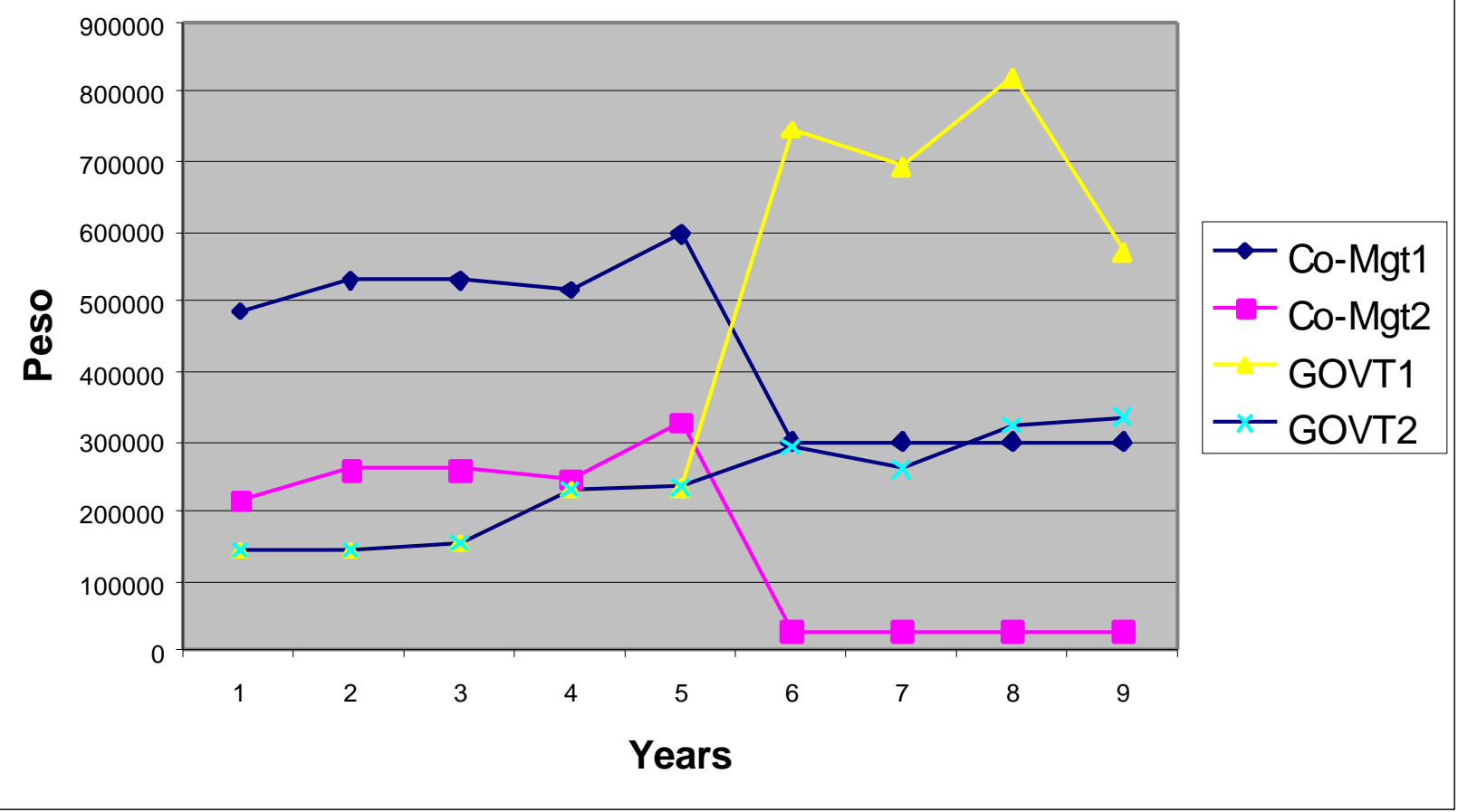




\section{SUMMARY OF TIME AND COST EXPENDITURES}

A. TIME

\begin{tabular}{cccc}
\hline & All $(\mathrm{N}=63)$ & Member $(\mathrm{N}=31)$ & Non-Member $(\mathrm{N}=32)$ \\
\hline Total Hours & 19,905 & 16,927 & 2,978 \\
Ave. Hours & 315.9 & 546.0 & 93.1 \\
\hline
\end{tabular}

B. COST EXPENDITURES

All $(\mathrm{N}=63) \quad$ Member $(\mathrm{N}=31) \quad$ Non-Member $(\mathrm{N}=32)$

Total Cost

62,337

46,446

15,891

Ave. Cost

989.5

$1,498.3$

496.6

C. BREAKDOWN OF COST EXPENDITURES

\begin{tabular}{lcccccc}
\hline \multicolumn{1}{c}{ ITEM } & \multicolumn{2}{c}{ All } & \multicolumn{2}{c}{ Member } & \multicolumn{2}{c}{ Non-Member } \\
\hline & FREQ. & $\%$ & FREQ. & $\%$ & FREQ. & $\%$ \\
\cline { 2 - 6 } 1) Gas/Transportation & 63 & 39.1 & 43 & 42.2 & 20 & 33.9 \\
2) Food & 31 & 19.3 & 19 & 18.6 & 12 & 20.3 \\
3) Cigarettes & 25 & 15.5 & 16 & 15.7 & 9 & 15.3 \\
4) Liqour/Gin & - & - & - & - & - & - \\
5) Lost Wages & 7 & 4.3 & 2 & 2.0 & 5 & 8.5 \\
6) Other Expenses & 35 & 21.7 & 22 & 21.6 & 13 & 22.0 \\
\hline TOTAL & 161 & 100 & 102 & 100 & 59 & 100 \\
\hline
\end{tabular}


Table 4 Breakdown of Time Spent on Activities in Co-Management System

Activity
1) Information Gathering
2) Attending Meetings
3) Trainings
4) Conflict Resolution
5) Monitoring
6) Communicating
7) Decision Making
8) Project Maintenace
9) Enforcement
10) Others

\begin{tabular}{|c|c|c|c|c|c|}
\hline & & ime Spe & tivities & & \\
\hline & Mean Hrs & & & $\%$ of Total & \\
\hline Members & N-Members & All & Members & N-Member & All \\
\hline 40.8 & 22.3 & 31.4 & 7.4725275 & 23.952739 & 9.939854 \\
\hline 38.4 & 10.8 & 24.4 & 7.032967 & 11.60043 & 7.723963 \\
\hline 18.2 & 7.3 & 12.7 & 3.3333333 & 7.8410311 & 4.02026 \\
\hline 10.3 & 2.8 & 6.5 & 1.8864469 & 3.0075188 & 2.057613 \\
\hline 322.5 & 1.1 & 159.2 & 59.065934 & 1.1815252 & 50.39569 \\
\hline 8.9 & 4.7 & 6.7 & 1.6300366 & 5.0483351 & 2.120924 \\
\hline 24.4 & 29.1 & 26.8 & 4.4688645 & 31.256713 & 8.483697 \\
\hline 75 & 13.2 & 43.6 & 13.736264 & 14.178303 & 13.80184 \\
\hline 1.6 & 0.06 & 0.8 & 0.2930403 & 0.0644468 & 0.253245 \\
\hline 6 & 1.8 & 3.9 & 1.0989011 & 1.9334049 & 1.234568 \\
\hline 546 & 93.1 & 315.9 & 100 & 100 & 100 \\
\hline
\end{tabular}

Activity
1) Information Gathering
2) Attending Meetings
3) Trainings
4) Conflict Resolution
5) Monitoring
6) Communicating
7) Decision Making
8) Project Maintenace
9) Enforcement
10) Others

Total Cost

$\begin{array}{lll}46446 & 15891 & 62337\end{array}$

\section{Cost Spent on Co-Mgt Activities}

\begin{tabular}{|c|c|c|c|c|c|}
\hline & \\
\hline Members & N-Members & All & Members & N-Member & All \\
\hline 9467 & 5238 & 14705 & 20.38281 & 32.962054 & 23.58952 \\
\hline 4072 & 3267 & 7339 & 8.7671705 & 20.558807 & 11.7731 \\
\hline 1190 & 3833 & 5023 & 2.5621151 & 24.120571 & 8.057815 \\
\hline 943 & 20 & 963 & 2.0303148 & 0.1258574 & 1.544829 \\
\hline 24467 & 135 & 24602 & 52.678379 & 0.8495375 & 39.46613 \\
\hline 0 & 0 & 0 & 0 & 0 & 0 \\
\hline 3428 & 1156 & 4584 & 7.380614 & 7.2745579 & 7.353578 \\
\hline 2057 & 1964 & 4021 & 4.428799 & 12.359197 & 6.450423 \\
\hline 0 & 0 & 0 & 0 & 0 & 0 \\
\hline 0 & 0 & 0 & 0 & 0 & 0 \\
\hline
\end{tabular}


